\title{
FAKTOR-FAKTOR YANG MEMPENGARUHI STRUKTUR MODAL BANK SYARIAH DI INDONESIA TAHUN 2014-2018
}

\author{
Hidayati Nasrah ${ }^{1}$ \& Nela Resni ${ }^{2}$ \\ ${ }^{1 \& 2}$ Fakultas Ekonomi dan Ilmu Sosial, Universitas Islam Negeri (UIN) Suska Riau \\ Email : hidayati.nasrah@uin-suska.ac.id,nellaresni91@gmail.com
}

\begin{abstract}
ABSTRAK
Penelitian ini bertujuan untuk mengetahui bagaimana pengaruh ukuran bank, profitabilitas, tangibilitas, pertumbuhan bank, likuiditas, Non Debt Tax Shield (NDTS), dan NPF terhadap leverage pada Bank Syariah. Penelitian ini menggunakan data sekunder yang diperoleh melalui situs perusahaan Bank Umum Syariah. Metode pemilihan sampel pada penelitian ini menggunakan teknik purposive sampling, sampel pada penelitian ini sebanyak 11 perusahaan. Analisis data menggunakan uji statistik deskriptif, uji asumsi klasik, dan uji hipotesis menggunakan metode regresi linier berganda. Hasil analisis regresi linier berganda menunjukkan bahwa secara simultan ukuran bank, tangibilitas, pertumbuhan bank, likuiditas dan perisai pajak bukan utang (NDTS) berpengaruh signifikan terhadap struktur modal (leverage). Secara parsial pada ukuran bank berpengaruh positif, sedangkan likuiditas berpengaruh negatif terhadap leverage. Hasil pada tangibilitas, pertumbuhan bank dan NDTS tidak berpengaruh terhadap leverage. Variabel independen dapat menjelaskan pengaruh leverage sebesar 71,6\% sedangkan sisanya sebesar 28,4\% dipengaruhi oleh faktor lain yang tidak dimasukkan dalam model regresi ini.
\end{abstract}

Kata kunci : Ukuran Bank, Tangibilitas, Pertumbuhan Bank, Likuiditas, NDTS, dan Leverage.

\begin{abstract}
This study aims to determine how the influence of bank size, tangibility, bank growth, liquidity and non-debt tax shields (NDTS) to leverage on Bank Syariah. This study uses secondary data obtained through the Sharia Commercial Bank company website. The sample selection method in this study uses purposive sampling technique, the sample in this study were 11 companies. Data analysis using descriptive statistical tests, classical assumptions test, and hypothesis testing using multiple linear regression methods. The results of multiple linear regression analysis show that simultaneously bank size, profitability, tangibility, bank growth, liquidity and non-debt tax shield (NDTS) have a significant effect on leverage. Partially, bank size has a positive effect, liquidity have a negative effect on leverage. The results on tangibility, bank growth and NDTS have no effect on leverage. The independent variable can explain the effect of leverage of $71.6 \%$ while the remaining $28.4 \%$ is influenced by other factors not included in this regression model
\end{abstract}

Keywords : Bank Size, Tangibility, Bank Growth, Liquidity, NDTS, and Leverage. 


\section{PENDAHULUAN}

Bank merupakan lembaga perantara keuangan yang menyalurkan dana dari pihak yang kelebihan dana (surplus unit) ke pihak yang kekurangan dana (deficit unit) pada kurun waktu yang ditentukan (Dendawijaya, 2009). Bank memiliki peranan penting dalam mendorong perekonomian nasional karena bank merupakan pengumpul dana dari surplus unit dan penyalur kredit kepada deficit unit, tempat menabung yang efektif dan produktif bagi masyarakat, serta memperlancar lalu lintas pembayaran bagi semua sektor perekonomian (Hasibuan, 2005).

Struktur modal merupakan
permasalahan penting bagi setiap perusahaan dan mendapatkan perhatian khusus, karena posisi finansial perusahaan dipengaruhi oleh baik buruknya struktur modal dari perusahaan tersebut. Perusahaan cenderung mengutamakan keuntungan pemilik perusahaan dan pemegang saham, Ariani dan Wiagustini (2017). Struktur modal memiliki tujuan untuk menentukan besar proporsi atas kombinasi sumber pendanaan yang digunakan, agar dapat memaksimalkan nilai perusahaan. Kombinasi sumber dana dibagi menjadi dua jenis, yaitu modal yang berasal dari dalam perusahaan dan modal yang berasal dari luar perusahaan. Modal yang berasal dari dalam perusahaan merupakan sumber dana internal dalam bentuk laba ditahan, sedangkan modal yang berasal dari luar perusahaan merupakan sumber dana eksternal dalam bentuk utang.

Dalam konteks Islamic Banking (IB), struktur modal terdiri dari kedua pemegang saham, ekuitas dan utang. Rekening investasi dan giro adalah sumber utama utang. Elemen signifikan utama yang mempengaruhi struktur modal adalah utang, karena merupakan bagian terbesar dari ibukota. IB mengumpulkan dana dari deposan untuk menginvestasikan uang mereka keuntungan dan risiko yang wajar oleh manajemen investasi profesional. Struktur modal adalah dianggap sebagai salah satu atribut paling substansial, yang memberlakukan kendala penting pada IB. Sebagai sebuah aturan, IB memiliki lebih banyak modal dari pada tingkat minimum yang diwajibkan oleh persyaratan modal secara berurutan untuk menghadapi potensi guncangan.

Salah satu bank di Indonesia yang saat ini telah berusaha melaksanakan prinsip syariah dalam kegiatan usahanya adalah Bank Muamalat. Kurang lebih dua bulan setelah ditetapkannya UndangUndang No. 7 tahun 1992 tentang perbankan yang memperkenalkan bank berdasarkan pada prinsip bagi hasil, Bank Muamalat melakukan operasi sesuai dengan prinsip Syariah Islam, yaitu tepatnya 1 Mei 1992. Persiapan pendirian Bank Muamalat tersebut sesungguhnya telah dilaksanakan beberapa saat sebelum ditetapkannya Undang-Undang No. 7 tahun 1992. Bank Muamalat memperoleh izin usaha dasar Keputusan Menteri Keuangan No. 430/KMK.013/1992 tanggal 24 april 1992. (Budisantoso dan Nuritomo, 2013)

Beberapa penelitian mengenai struktur modal telah dilakukan oleh para peneliti sebelumnya diantaranya. Yuliana dan Yuyetta (2017) penelitian menunjukkan bahwa ukuran, sumber daya yang dihasilkan, biaya utang, dan likuiditas memiliki negatif efek dengan signifikansi statistik pada leverage. Reputasi memiliki efek positif dengan statistik signifikansi pada leverage. Tingkat waran tidak memiliki pengaruh signifikan terhadap leverage, namun ditemukan bahwa itu memiliki efek positif. Peluang pertumbuhan ternyata tidak memiliki signifikansi berpengaruh pada leverage, namun ditemukan bahwa itu memiliki efek negatif. Implikasi dari 
penelitian ini menunjukkan bahwa ukuran, sumber daya yang dihasilkan, biaya utang, likuiditas, dan peluang pertumbuhan dapat menurun pengaruh. Namun, reputasi dan tingkat waran dapat meningkatkan leverage.

Menurut penelitian yang dilakukan oleh (Bukair, 2018) Hasil menunjukkan bahwa ukuran bank, likuiditas dan usia perusahaan adalah positif terkait dengan rasio leverage bank syariah GCC, mendukung trade-off teori. Tidak konsisten dengan prediksi teoritis, ditemukan bahwa profitabilitas, tangibilitas dan pertumbuhan memiliki hubungan positif yang tidak signifikan dengan tingkat leverage, menunjukkan ini penentu tidak penting dalam keputusan struktur modal. Selanjutnya, domestik bruto produk (PDB) dan perisai pajak bukan utang memiliki efek negatif pada rasio leverage, dan signifikan untuk PDB. Menurut penelitian yang telah dilakukan (Deitiana \& Anggraini, 2014). Dari hasil penelitian, terlihat bahwa hanya variabel firm size dan liquidity yang berpengaruh terhadap leverage, sementara sisanya tidak berpengaruh terhadap leverage.

Penelitian yang dilakukan (Ariani dan Wiagustini, 2017) menunjukan bahwa profitabilitas berpengaruh negatif signifikan terhadap struktur modal, struktur aktiva berpengaruh positif signifikan terhadap struktur modal, peluang perumbuhan berpengaruh positif signifikan terhadap struktur modal, NDTS berpengaruh negatif signifikan terhadap struktur modal dan ukuran perusahaan berpengaruh negatif signifikan terhadap struktur modal.

\section{TINJAUAN PUSTAKA}

\section{Bank Syariah}

Dalam Pasal 1 Undang-undang No. 21 Tahun 2008 tentang perbankan syariah, disebutkan bahwa bank adalah badan usaha yang menghimpun dana masyarakat dalam bentuk simpanan dan menyalurkannya kepada masyarakat dalam bentuk kredit dan atau bentukbentuk lainnya dalam rangka meningkatkan taraf hidup rakyat banyak.

Definisi lainnya, bank syariah merupakan bank yang beroperasi dengan tidak mengandalkan pada bunga atau lembaga keuangan yang operasional produknya dikembangkan berlandaskan Alquran dan hadits (Machmud dan Rukmana, 2010).

Hal ini juga sesuai dengan QS Asy Syu'ara ayat 181-184:

Artinya: "Sempurnakanlah takaran dan janganlah kamu termasuk orang-orang yang merugikan dan timbanglah dengan timbangan yang lurus. Dan janganlah kamu merugikan manusia pada hakhaknya dan janganlah kamu merajalela di muka bumi dengan membuat kerusakan dan bertawakalah kepada Allah yang telah menciptakan kamu dan umat-umat yang dahulu."

Di Indonesia, bank syariah itu sendiri terbagi dalam dua bentuk, yaitu Bank Umum Syariah (BUS) dan Unit Usaha Syariah (UUS). BUS adalah bank syariah yang kegiatannya memberikan jasa dalam lalu lintas pembayaran. UUS adalah unit kerja dari kantor pusat bank umum konvensional yang berfungsi sebagai kantor induk dari kantor atau unit yang melaksanakan kegiatan usaha berdasarkan prinsip syariah (Yaya, Martawireja, dan Abdurahim, 2009).

\section{Skema Pembiayaan Bagi Hasil}

Struktur modal adalah bagian terpenting dalam perusahaan, karena struktur modal berperan sebagai sumber pendanaan perusahaan yang menggambarkan bagaimana perusahaan didanai. Struktur modal merupakan kombinasi antara utang, saham preferen, dan ekuitas biasa dalam struktur keuangan jangka panjang (Horne dan Warchowicz, 2012). Struktur modal memiliki tujuan 
untuk menentukan besar proporsi atas kombinasi sumber pendanaan yang digunakan, agar dapat memaksimalkan nilai perusahaan. Kombinasi sumber dana dibagi menjadi dua jenis, yaitu modal yang berasal dari dalam perusahaan dan modal yang berasal dari luar perusahaan. Modal yang berasal dari dalam perusahaan merupakan sumber dana internal dalam bentuk laba ditahan, sedangkan modal yang berasal dari luar perusahaan merupakan sumber dana eksternal dalam bentuk utang.

Perusahaan sebagai penerima amanat mempunyai tanggungjawab atas kegiatan operasional sehingga mampu mendatangkan keuntungan bagi pihak yang berkepentingan dengan perusahaan. Dalam menjalankan amanat, perusahaan dituntut adil dalam bagi semua pihak sehingga tidak ada satupun pihak yang merasa dirugikan. Hal ini sesuai dengan kaidah Islam yang terdapat pada firman Allah SWT dalam surat an-Nisa ayat 58:

Artinya : "Sesungguhnya Allah menyuruh kamu menyampaikan amanat kepada yang berhak menerimanya, dan (menyuruh kamu) apabila menetapkan hukum di antara manusia supaya kamu menetapkan dengan adil. Sesungguhnya Allah memberi pengajaran yang sebaik-baiknya kepadamu. Sesungguhnya Allah adalah Maha mendengar lagi Maha Melihat”.

\section{Ukuran Bank}

Ukuran perusahaan dalam hal ini bank merupakan ukuran atau besarnya aset yang dimiliki oleh perusahaan. Besar kecilnya perusahaan dapat diukur berdasarkan total penjualan, total nilai buku asset, nilai total aktiva dan jumlah tenaga kerja. Ukuran perusahaan (size) dalam jangka panjang merupakan wujud pertumbuhan yang baik. Pengukuran terhadap ukuran perusahaan diproksikan dengan nilai logaritma natural dari total aktiva (logaritma natural of total assets).
Ukuran Perusahaan $($ Firm Size $)=$ Ln Total Asset

\section{Tangibilitas}

Tangibilitas merupakan salah satu variabel penting dalam menentukan keputusan pendanaan, karena aktiva tetap yang dimiliki oleh suatu perusahaan dapat dijadikan collateral bagi pihak kreditur dalam melakukan pinjaman (Joni dan Lina, 2010). Perusahaan yang tidak mempunyai aktiva yang dapat digunakan sebagai collateral oleh perusahaan dalam melakukan pinjaman, maka perusahaan tersebut akan cenderung menggunakan hutang dalam jumlah besar (Brigham \& Weston, 2014)

\section{Pertumbuhan Bank}

Menurut Usman (2014), sebuah perusahaan yang tumbuh akan memiliki tingkat leverage yang tinggi. Pertumbuhan yang lebih cepat dapat meningkatkan kebutuhan akan sumber dana eksternal (Mondher, 2012). Hasil penelitian Cortez dan Susanto (2012) menunjukkan bahwa pertumbuhan berpengaruh positif terhadap leverage. Hasil penelituian Rifai, Arifati dan Magdalena M. (2015), bahwa terdapat hubungan positif pertumbuhan dengan semua jenis utang, lebih relevannya yaitu dengan hutang jangka pendek.

\section{Growth $=\underline{\text { Total Aset }}{ }^{\mathrm{t}}$ - Total Aset ${ }^{\mathrm{t}-1}$ \\ Total Aset ${ }^{\mathrm{t}-1}$}

\section{Likuiditas}

Likuiditas merupakan kemampuan perusahaan untuk memenuhi kewajiban yang harus segera dibayar dengan harta lancar yang dimiliki perusahaan. Perusahaan yang mampu memenuhi kewajiban secara tepat waktu berarti perusahaan tersebut berada dalam kondisi yang liquid. Kondisi yang liquid menunjukkan bahwa perusahaan memiliki alat pembayaran atau aktiva lancar yang lebih besar dibandingkan dengan utang. Kondisi perusahaan yang memiliki 
likuiditas yang tinggi berarti memiliki aktiva lancar yang besar. Besarnya jumlah aktiva lancar yang dimiliki, mencerminkan bahwa perusahaan mampu untuk mendanai kegiatan operasional dengan sumber dana internal, sehingga perusahaan tidak lagi membutuhkan utang. Oleh karena itu, tingkat utang perusahaan menurun, dalam penelitian Bukhair (2018).

\section{Current Ratio $=\underline{\text { Aktiva Lacar }}$ \\ Utang Lancar}

\section{Non Debt Tax Shield (NDTS)}

Manfaat hutang dapat dianggap sebagai biaya untuk menggantikan pajak (Modigliani dan Miller, 1958). Manfaat dari pelindung pajak ini mendorong perusahaan untuk menerbitkan utang. Selain hutang, penyusutan aset tetap dan kredit pajak investasi adalah dua jenis Non Debt Tax Shield (NDTS), yang dapat mengimbangi pembayaran pajak. DeAngelo dan Masulis (1980) berpendapat itu NDTS dapat diperhatikan sebagai alternatif untuk kepentingan pajak pendanaan utang, dan perusahaan dengan NDTS besar cenderung meminjam lebih sedikit utang.

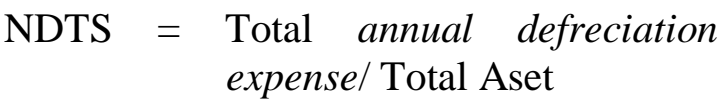

\section{METODE PENELITIAN}

\section{Desain Penelitian}

Pada dasarnya jenis penelitian dapat dikelompokkan menurut tujuan, metode, tingkat ekplansi, analisis dan jenis data. Menurut metodenya, jenis penelitian dalam penelitian ini adalah penelitian kuantitatif menggunakan data sekunder.

Populasi adalah kumpulan dari elemen-elemen yang mempunyai karakteristik tertentu yang dapat digunakan untuk membuat kesimpulan. Elemen tersebut dapat berupa orang, manajer, auditor, perusahaan, peristiwa atau segala sesuatu yang menarik untuk diamati atau diteliti (Candrarin, 2017). Populasi dalam penelitian ini adalah bank umum syariah di Indonesia, yang terdiri dari 13 bank syariah.

Sampel adalah kumpulan subjek yang mewakili populasi. Sampel yang diambil harus mempunyai karakeristik yang sama dengan populasinya dan harus mewakili (representative) anggota populasi (Candrarin, 2017). Pengambilan sampel ini adalah dengan melakukan teknik purposive sampling yaitu metode pengambilan sampel berdasarkan kriteriakriteria tertentu. Proses seleksi sampel didasarkan oleh kriteria time series yang ditetapkan. Kriteria yang digunakan dalam menentukan sampel yaitu, bank-bank syariah yang ada di Indonesia yang menerbitkan laporan keuangan secara lengkap dengan jangka waktu 2014-2018. Dalam penentuannya ditetapkan kriteria sebagai berikut :

a. Bank syariah yang termasuk ke dalam bank umum syariah di Indonesia

b. Bank Umum Syariah yang tidak terdaftar di OJK berturut-turut selama 2014-2018

c. Bank Syariah yang tidak memiliki kelengkapan data yang dibutuhkan pada penelitian ini. 
Tabel 1. Kriteria Sampel

\begin{tabular}{clc}
\hline No. & \multicolumn{1}{c}{ Keterangan } & Jumlah \\
\hline 1 & $\begin{array}{l}\text { Bank syariah yang termasuk kedalam bank umum syariah di } \\
\text { Indonesia }\end{array}$ & 13 \\
\hline 2 & $\begin{array}{l}\text { Bank Umum Syariah yang tidak terdaftar di OJK berturut-turut } \\
\text { selama 2014-2018 }\end{array}$ & (1) \\
\hline 3 & $\begin{array}{l}\text { Bank Syariah yang tidak memiliki kelengkapan data yang } \\
\text { dibutuhkan pada penelitian ini }\end{array}$ & 11 \\
\hline & Jumlah sampel penelitian \\
\hline
\end{tabular}

Berdasarkan dengan kriteriakriteria yang telah ditentukan diperoleh sebanyak 11 bank umum syariah yang akan dijadikan sampel penelitian.

Teknik Analisis Data Analisis Statistik Deskriptif

Menurut Chandrarin (2017)
statistik deskriptif bertujuan untuk
menguji dan menjelaskan karakteristik
sampel yang di observasi, hasil uji
statistik deskriptif biasanya berupa tabel
yang setidaknya berisi nama variabel yang
di observasi, mean, standar deviasi,
maksimum dan minimum yang kemudian
di ikuti penjelasan berupa narasi yang
menjelaskan isi tabel tersebut.

\section{Metode Regresi Berganda}

Data yang dikumpulkan dalam penelitian ini akan diolah dan kemudian dianalisis dengan uji analisis berganda. Selain mengukur kekuatan hubungan antara dua variabel atau lebih, juga menunjukkan arah hubungan antara variabel dependen dan variabel independen (Ghozali, 2013).

Dalam penelitian ini variabel independen yang digunakan adalah ukuran perusahaan dalam hal ini bank (X1), tangibilitas (X2), pertumbuhan bank (X3), likuiditas (X4) dan Non Debt Tax Shield (X5)

Berikut ini adalah rumus regresi berganda:

Yit $=a+b 1$ SIZE + b2 TANG + b3

GROWTH + b4 LIQUID + b5 NDTS + e

Keterangan :

Y

$\mathrm{a}$

: Struktur Modal

a : Konstanta

SIZE : Ukuran Bank

TANGT : Tangibilitas

GROWTH : Pertumbuhan Bank

LIQUID : Likuiditas

NDTS : Non Debt Tax Shield

e : Standar eror

\section{HASIL DAN PEMBAHASAN}

\section{Pengujian Data}

Pengujian data dalam penelitian ini dilakukan dengan menggunakan data-data yang terdapat dalam laporan keuangan perbankan syariah periode 2014-2018 yang dilakukan dengan menggunakan SPSS versi 25. Data penelitian diperoleh melalui situs resmi masing-masing perusahaan dan OJK. 
Tabel 2. Daftar Nama Bank Umum Syariah yang dijadikan Sampel

\begin{tabular}{cl}
\hline No. & \multicolumn{1}{c}{ Nama Bank Umum Syariah } \\
\hline 1 & PT Bank Central Asia Syariah \\
\hline 2 & PT Bank Syariah Bukopin \\
\hline 3 & PT Bank Syariah Mandiri \\
\hline 4 & PT Bank Victoria Syariah \\
\hline 5 & PT Bank Mega Syariah \\
\hline 6 & PT Bank Muamalat Indonesia \\
\hline 7 & PT Bank Negara Indonesia Syariah \\
\hline 8 & PT Bank Panin Dubai Syariah \\
\hline 9 & PT Bank Rakyat Indonesia Syariah \\
\hline 10 & PT Bank Jabar Banten Syariah \\
\hline 11 & PT Bank Tabungan Pensiunan Nasional Syariah \\
\hline & $\quad$ Sumber : Data Olahan (2020)
\end{tabular}

Populasi pada penelitian sebanyak 13 bank umum syariah, dengan menggunakan purposive sampling yaitu penentuan sampel berdasarkan kriteria tertentu maka sampel pada penelitian ini berjumlah 11 Bank Umum Syariah.

\section{Hasil Analisis Statistik Deskriptif}

Hasil akhir dari pemilihan sampel penelitian ini didapatkan 11 bank umum syariah yang memiliki data lengkap dan kemudian menjadi 55 data observasi.

Tabel 3. Hasil Statistik Deskriptif

\begin{tabular}{lccccc}
\hline \multicolumn{5}{c}{ Descriptive Statistics } \\
\hline Size & $\mathrm{N}$ & Minimum & Maximum & Mean & Std. Deviation \\
\hline Tangibilitas & 55 & 27,95 & 32,22 & 30,0728 & 1,14837 \\
\hline Growth & 55 &, 0006 &, 0610 &, 020880 &, 0168602 \\
\hline Likuiditas & 55 &,- 228 & 11,583 &, 34594 & 1,551027 \\
\hline NTDS & 55 & 2,941 & 16,556 & 6,98669 & 2,671251 \\
\hline StrukturModal & 55 &, 0004 &, 0267 &, 009685 &, 0065464 \\
\hline Valid N (listwise) & 55 &, 3740 & 3,4964 & 1,427334 &, 8144950 \\
\hline
\end{tabular}

Sumber : Data Olahan (2020)

Berdasarkan Tabel 3 menjelaskan data variabel ukuran bank (size) memiliki niliai terrendah sebesar 27,95 yang dimiliki oleh PT Bank Victoria Syariah pada tahun 2015, nilai tertinggi sebesar 32,2195 yang dimiliki oleh PT Bank Syariah Mandiri pada tahun 2018, nilai rata-rata ukuran bank sebesar 30,0728, dengan nilai standar deviasi sebesar 1,14837 .

Pada data variabel tangibilitas memiliki niliai terrendah sebesar 0,0006 yang dimiliki oleh PT Bank Victoria Syariah pada tahun 2018, nilai tertinggi sebesar 0,0610 yang dimiliki oleh PT Bank Mega Syariah pada tahun 2015, nilai rata-rata tangibilitas sebesar 0,020880, dengan nilai standar deviasi sebesar 0,0168602 .

Pada data variabel pertumbuhan bank memiliki niliai terrendah sebesar 0,2277 yang dimiliki oleh PT Bank Mega Syariah pada tahun 2014, nilai tertinggi sebesar 11,5833 yang dimiliki oleh PT Bank Tabungan Pensiunan Nasional Syariah pada tahun 2014, nilai rata-rata pertumbuhan bank sebesar 0,345939, 
dengan nilai standar deviasi sebesar 1,5510267 .

Pada data variabel likuiditas memiliki niliai terrendah sebesar 2,941 yang dimiliki oleh PT Bank Rakyat Indonesia Syariah pada tahun 2018, nilai tertinggi sebesar 16,556 yang dimiliki oleh PT Bank Negara Indonesia Syariah pada tahun 2015, nilai rata-rata likuiditas sebesar 6,98669, dengan nilai standar deviasi sebesar 2,671251.
Pada data variabel NDTS memiliki niliai terrendah sebesar 0,0004 yang dimiliki oleh PT Bank Panin Dubai Syariah pada tahun 2016, nilai tertinggi sebesar 0,0267 yang dimiliki oleh PT Bank Tabungan Pensiunan Nasional Syariah pada tahun 2017, nilai rata-rata NDTS sebesar 0,009685, dengan nilai standar deviasi sebesar 0,0065464.

\section{Hasil Uji Asumsi Klasik \\ Uji Normalitas}

Tabel 4. Hasil Uji Normalitas

\begin{tabular}{llr}
\hline \multicolumn{3}{c}{ One-Sample Kolmogorov-Smirnov Test } \\
\hline $\mathrm{N}$ & \multicolumn{1}{c}{ Unstandardized Residual } \\
\hline Normal Parameters ${ }^{\mathrm{a}, \mathrm{b}}$ & Mean & 55 \\
\cline { 2 - 3 } & Std. Deviation & 1.427334 \\
\hline Most Extreme Differences & Absolute & .8144950 \\
\cline { 2 - 3 } & Positive & .139 \\
\cline { 2 - 3 } & Negative &. .098 \\
\hline Test Statistic & & .139 \\
\hline Asymp. Sig. (2-tailed) & & $.162^{\mathrm{c}}$ \\
\hline a. Test distribution is Normal. & & \\
\hline
\end{tabular}

Sumber : Data Olahan (2020)

Berdasarkan Tabel 4 dapat dilihati nilai signifikan dari kolmogorv-smirnov sebesar 0,162 lebih besar dari 0,05, artinya berdasarkan kriteria keputusan data penelitian ini berdistribusi normal.

Uji Multikolinearitas

Tabel 5. Hasil Uji Multikolinearitas

\begin{tabular}{llll}
\hline \multicolumn{3}{c}{ Coefficients $^{\mathbf{a}}$} \\
& \multicolumn{2}{c}{ Collinearity Statistics } \\
\cline { 2 - 4 } Model & Tolerance & VIF \\
\hline 1 & (Constant) & & \\
\cline { 2 - 4 } & Ukuran Bank & .764 & 1.309 \\
\cline { 2 - 4 } & Tangibilitas & .802 & 1.247 \\
\cline { 2 - 4 } & Pertumbuhan Bank & .947 & 1.056 \\
\cline { 2 - 4 } & Likuiditas & .779 & 1.283 \\
\cline { 2 - 4 } & NDTS & .682 & 1.466 \\
\hline
\end{tabular}

Sumber : Data olahan (2020)

Berdasarkan Tabel 5 dapat dilihat nilai tolerance variabel Ukuran Bank sebesar 0,764, variabel Tangibilitas sebesar 0,802, variabel Pertumbuhan Bank sebesar 0,947, variabel Likuiditas sebesar
0,779 dan variabel NDTS sebesar 0,682 , Nilai tolerance masing-masing variabel independen lebih besar dari 0,01.

Untuk nilai VIF variabel Ukuran Bank sebesar 1,309, variabel Tangibilitas 
sebesar 1,247, variabel Pertumbuhan Bank sebesar 1,056, variabel Likuiditas sebesar 1,283 dan variabel NDTS sebesar 1.466. Nilai VIF masing-masing variabel independen kurang dari 10. Artinya masing-masing variabel independen tidak terjadi korelasi atau tidak terjadi multikolinieiritas.

\section{Uji Heterokedastisitas}

Deteksi ada tidaknya heteroskedastisitas dilakukan dengan melihat ada tidaknya pola tertentu pada grafik scatterplot yang diperlihatkan pada gambar berikut:

\section{Gambar 1. Grafik Scatterplot}

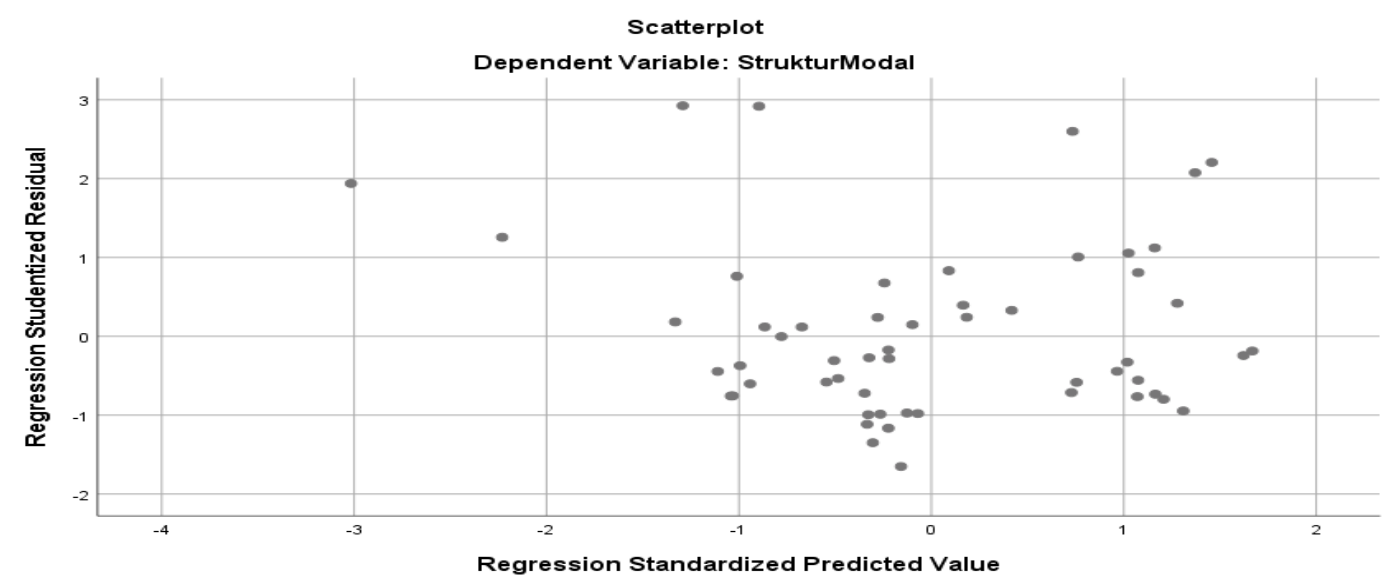

Sumber : Data Olahan (2020)

\section{Uji Autokorelasi}

Tabel 6. Hasil Uji Autokorelasi

\begin{tabular}{lccccc}
\hline \multicolumn{6}{c}{ Model Summary $^{\mathbf{b}}$} \\
\hline Model & $\mathrm{R}$ & R Square & Adjusted R Square & $\begin{array}{c}\text { Std. Error of the } \\
\text { Estimate }\end{array}$ & Durbin-Watson \\
\hline 1 & $.868^{\mathrm{a}}$ & .753 & .716 & .4338977 & 1.944 \\
\hline
\end{tabular}

Sumber : Data Olahan (2020)

Berdasarkan Tabel 6 dapat dilihat durbin-watson sebesar 1,944, untuk nilai dl sebesar 1,2940, dan nilai du sebesar 1,8607. Artinya berdasarkan nilai tersebut dapat disimpulkan tidak terjadi autokorelasi positif dan negatif, karena nilai $\mathrm{du}=1,8607<\mathrm{dw}=1,944<4$ $d u=2,1393(d u<d<4-d u)$.

\section{Analisis Regresi Linier Berganda}

Pada analisis ini untuk mengetahui nilai dari koefisien regresi (B) dan alasan mengenai koefisien regresi yang bernilai positif dan negatif. Berikut adalah tabel hasil dari pengujian regresi linier berganda. 
Tabel 7. Hasil Analisis Regresi Linier

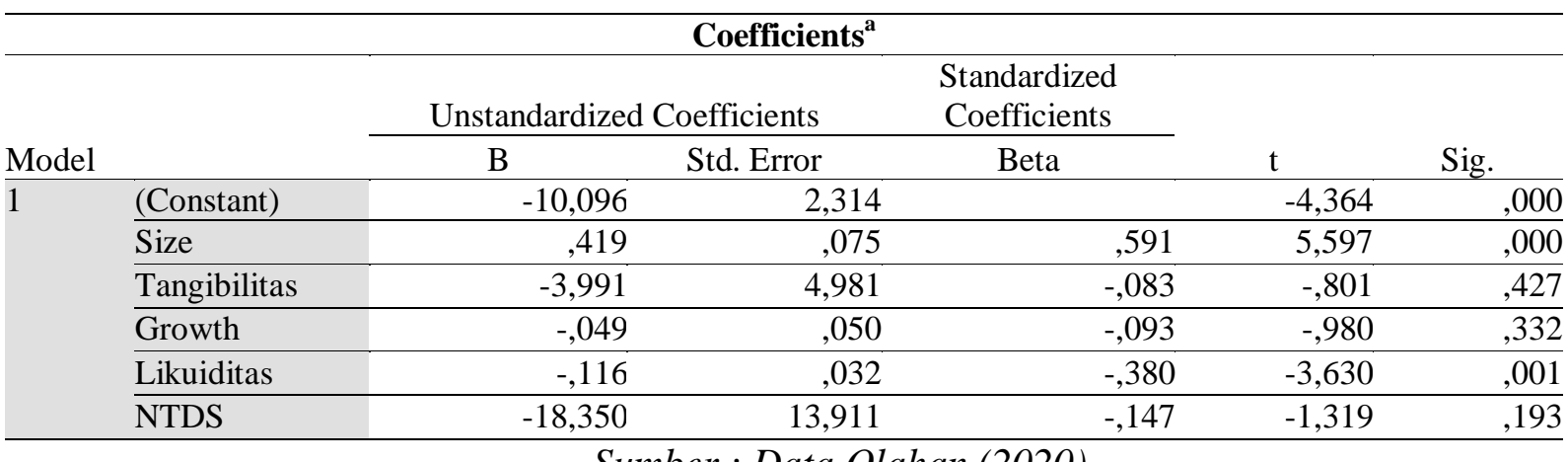

Sumber : Data Olahan (2020)

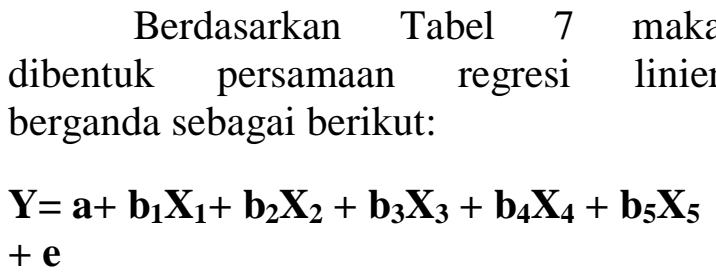

$Y=-10,096+0,419 X_{1}-3,991 X_{2}-0,49 X_{3}$ $--0,116 X_{4}-18,350 X_{5}+e$

Persamaan regresi tersebut dapat dijelaskan sebagai berikut:

a. Konstanta sebesar $-10,096$ artinya jika variabel independen tetap maka variabel dependen struktur modal (DER) nilainya adalah sebesar 10,096 .

b. Koefisien regresi variabel Ukuran Bank adalah sebesar 0,419 artinya jika variabel independen lain nilainya tetap dan Ukuran Bank mengalami kenaikan 1 dalam satuan, maka DER akan mengalami peningkatan sebesar 0,419. Koefisien bernilai positif artinya terjadi hubungan positif antara Ukuran Bank dengan DER.

c. Koefisien regresi variabel Tangibilitas adalah sebesar -3,991 artinya jika variabel independen lain nilainya tetap dan Tangibilitas mengalami kenaikan 1 dalam satuan, maka DER akan mengalami penurunan sebesar 3,991. Koefisien bernilai negatif artinya terjadi hubungan negatif antara Tangibilitas dengan DER. d. Koefisien regresi variabel Pertumbuhan Bank adalah sebesar 0,49 artinya jika variabel independen lain nilainya tetap dan Pertumbuhan Bank mengalami kenaikan 1 dalam satuan, maka DER akan mengalami penurunan sebesar 0,49. Koefisien bernilai negatif artinya terjadi hubungan negatif antara Pertumbuhan Bank dengan DER.

e. Koefisien regresi variabel Likuiditas adalah sebesar -0,116 artinya jika variabel independen lain nilainya tetap dan Likuiditas mengalami kenaikan 1 dalam satuan, maka DER akan mengalami penurunan sebesar 0,116. Koefisien bernilai negatif artinya terjadi hubungan negatif antara Likuiditas dengan DER.

f. Koefisien regresi variabel NDTS adalah sebesar $-18,350$ artinya jika variabel independen lain nilainya tetap dan NDTS mengalami kenaikan 1 dalam satuan, maka DER akan mengalami peningkatan sebesar 18,350. Koefisien bernilai negatif artinya terjadi hubungan negatif antara NDTS dengan DER.

\section{Pengaruh Ukuran Bank Terhadap Struktur Modal}

Hipotesis pertama yang diajukan bahwa ukuran bank berpengaruh terhadap struktur modal, pada hasil regresi linier berganda menunjukkan ukuran bank mempunyai hubungan positif terhadap 
struktur modal dengan nilai koefisien 0,419. Hasil uji secara parsial menunjukkan nilai signifikan ukuran bank sebesar 0,000 lebih rendah dari $\alpha 0,05$, yang artinya ukuran bank berpengaruh positif terhadap struktur modal. Berdasarkan hasil tersebut hipotesis pertama yang menyatakan ukuran bank berpengaruh terhadap struktur modal diterima.

Berdasarkan hasil tersebut dapat dijelaskan bahwa semakin besar ukuran bank yang dinilai dengan total aset dapat meningkatkan nilai struktur modal pada bank. Dari perspektif Islam, IB yang lebih besar memiliki biaya kebangkrutan yang lebih sedikit karena mereka sifat kontrak bisnis yang harus mematuhi prinsipprinsip syariah, telah terdiversifikasi portofolio, dan risiko investasi yang lebih rendah. Karena itu, para IB lebih suka meminjam lebih banyak utang dari pada membiayai yang baru proyek.

Banyak bank harus membiayai sejumlah besar peluang investasi yang menguntungkan. Menurut teori trade-off, perusahaan yang memiliki aset berwujud ekstra memiliki leverage yang lebih tinggi rasio. Hasil ini sejalan dengan Maulina dkk (2018), dan Edward (2017) menyatakan ukuran perusahaan yang diukur dengan aset berpengaruh terhadap leverage.

\section{Pengaruh Tangibilitas Struktur Modal}

Hipotesis kedua yang diajukan bahwa tangibilitas berpengaruh terhadap struktur modal, pada hasil regresi linier berganda menunjukkan tangibilitas mempunyai hubungan negatif terhadap struktur modal dengan nilai koefisien 3,991. Hasil uji secara parsial menunjukkan nilai signifikan tangibilitas sebesar 0,427 lebih tinggi dari $\alpha$ 0,05, yang artinya tangibilitas tidak berpengaruh terhadap struktur modal. Berdasarkan hasil tersebut hipotesis kedua yang menyatakan tangibilitas berpengaruh terhadap struktur modal ditolak.

Berdasarkan hasil tersebut dapat dijelaskan bahwa semakin besar aset berwujud yang dimiliki perusahaan akan membuat perusahaan menambah utangnya. Perusahaan dengan sejumlah besar aset berwujud dapat memaksimalkan utang karena mereka memiliki kemampuan untuk melakukannya membayar kreditur lebih dari perusahaan dengan porsi rendah dari aset ini. Hasil ini tidak sejalan dengan Edward (2017) menemukan dampak negatif pada struktur modal bank yang diukur dengan leverage keuangan dan sejalan dengan penelitian Bukair (2018) yang menyatakan tangibilitas perusahaan tidak berpengaruh terhadap leverage.

\section{Pengaruh Pertumbuhan Bank Terhadap Struktur Modal}

Hipotesis ketiga yang diajukan bahwa pertumbuhan bank berpengaruh terhadap leverage, pada hasil regresi linier berganda menunjukkan pertumbuhan bank mempunyai hubungan negatif terhadap leverage dengan nilai koefisien $-0,49$. Hasil uji secara parsial menunjukkan nilai signifikan pertumbuhan bank sebesar 0,760 lebih besar dari $\alpha 0,05$, yang artinya pertumbuhan bank tidak berpengaruh terhadap leverage. Berdasarkan hasil tersebut hipotesis ketiga yang menyatakan pertumbuhan bank berpengaruh terhadap leverage ditolak.

Berdasarkan hasil tersebut dapat dijelaskan bahwa tinggi atau rendahnya pertumbuhan bank tidak mempengaruhi bank dalam meningkatkan utangnya. Hal ini mungkin dikarenakan adanya kebutuhan perusahaan dalam membiayai operasionalnya sehingga perusahaan akan tetap melakukan pinjaman atau utang walaupun pertumbuhannya meningkat atau tidak. 
Hasil ini sejalan dengan penelitian dari Maulina dkk (2018), Yusintha dan Suryandari (2010) yang menyatakan pertumbuhan perusahaan tidak berpengaruh terhadap leverage. Hasil ini juga tidak sejalan dengan hasil penelitian dari Edward (2017) yang menyatakan pertumbuhan perusahaan berpengaruh terhadap leverage.

\section{Pengaruh Likuiditas Terhadap Struktur Modal}

Hipotesis keempat yang diajukan bahwa likuiditas berpengaruh terhadap struktur modal, pada hasil regresi linier berganda menunjukkan likuiditas mempunyai hubungan negatif terhadap struktur modal dengan nilai koefisien 0,116. Hasil uji secara parsial menunjukkan nilai signifikan likuiditas sebesar 0,001 lebih rendah dari $\alpha 0,05$, yang artinya likuiditas berpengaruh negatif terhadap struktur modal. Berdasarkan hasil tersebut hipotesis keempat yang menyatakan likuiditas berpengaruh terhadap struktur modal diterima.

Hasil ini menjelaskan bahwa semakin besar likuiditas yang dimiliki perusahaan akan dapat mempengaruhi perusahaan akan mengurangi leveragenya. Kondisi yang liquid menunjukan bahwa perusahaan memiliki alat pembayaran atau aktiva lancar yang lebih besar dibandingkan dengan utang. Kondisi perusahaan yang memiliki likuiditas yang tinggi berarti memiliki aktiva lancar yang besar. Besarnya jumlah aktiva lancar yang dimiliki mencerminkan bahwa perusahaan mampu untuk mendanai kegiatan operasional dengan sumber dana internal, sehingga perusahaan tidak lagi membutuhkan utang.

Hal ini sesuai dengan pecking order theory yang menjelaskan bahwa perusahaan dengan likuiditas yang tinggi memiliki hubungan negatif terhadap tingkat utang, karena ketika kebutuhan modal sudah dapat terpenuhi dengan aktiva lancar, maka modal yang berasal dari utang pada pihak eksternal tidak lagi dibutuhkan. Oleh karena itu, semakin tinggi tingkat likuiditas perusahaan, maka semakin tidak diperlukan untuk melakukan utang.

Hasil ini sejalan dengan penelitian dari Yuliana dan Yuyetta (2017) yang menyatakan likuiditas berpengaruh negatif terhadap leverage. Hasil ini juga tidak sejalan dengan hasil penelitian dari Firmanullah dan Darsono (2017) yang menyatakan likuiditas tidak berpengaruh terhadap leverage.

\section{Non Debt Tax Shield (NDTS) Terhadap Leverage}

Hipotesis kelima yang diajukan bahwa Non Debt Tax Shield (NDTS) berpengaruh terhadap struktur modal, pada hasil regresi linier berganda menunjukkan Non Debt Tax Shield (NDTS) mempunyai hubungan negatif terhadap struktur modal dengan nilai koefisien -18,350. Hasil uji secara parsial menunjukkan nilai signifikan Non Debt Tax Shield (NDTS) sebesar 0,193 lebih besar dari $\alpha$ 0,05, yang artinya Non Debt hipotesis keenam yang menyatakan perisai Non Debt Tax Shield (NDTS) berpengaruh Tax Shield (NDTS) tidak berpengaruh terhadap struktur modal. Berdasarkan hasil tersebut terhadap struktur modal ditolak.

Hasil ini menjelaskan bahwa tinggi atau rendahnya perisai pajak yang diukur dengan penyusutan dari aset tetap tidak mempengaruhi perusahaan dalam meningkatkan leverage. Hal ini mungkin dikarenakan pengakuan penyusutan dapat berbeda antara PSAK dengan undangundang perpajakan, sehingga tidak ada alasan bagi perusahaan untuk meningkatkan utang demi mengurangi beban pajaknya. Hasil ini sejalan dengan hasil penelitian Deitiana dan Angraini 
(2014) yang menyatakan NDTS tidak berpengaruh terhadap leverage.

\section{KESIMPULAN}

Berdasarkan hasil analisis yang dilakukan, maka dapat diambil kesimpulan sebagai berikut :

1. Ukuran perusahaan (size) berpengaruh terhadap struktur modal (leverage). Dengan demikian hipotesis awal yang menyatakan bahwa ukuran perusahaan berpengaruh terhadap struktur modal (leverage) diterima.

2. Tangibilitas tidak berpengaruh terhadap struktur modal (leverage). Dengan demikian hipotesis awal yang menyatakan bahwa Tangibilitas berpengaruh terhadap struktur modal (leverage) ditolak.

3. Growth tidak berpengaruh terhadap struktur modal (leverage). Dengan demikian hipotesis awal yang menyatakan bahwa Growth berpengaruh terhadap struktur modal (DER) ditolak.

4. Likuiditas berpengaruh terhadap struktur modal (leverage). Dengan demikian hipotesis awal yang menyatakan bahwa Likuiditas berpengaruh terhadap struktur modal (leverage) diterima.

5. Non Debt Tax Shield (NDTS) tidak berpengaruh terhadap Struktur Modal (leverage). Dengan demikian hipotesis awal yang menyatakan bahwa Non Debt Tax Shield (NDTS) berpengaruh terhadap struktur modal (leverage) ditolak.

\section{DAFTAR PUSTAKA}

Ariani, N. K. A., \& Wiagustini, N. L. P. 2017. Faktor-Faktor yang Mempengaruhi Struktur Modal Perusahaan Property dan Real Estate yang Terdaftar di BEI. Manajemen Unud, 6(6), 3168-3195.
Brigham, E., \& Weston, J. 2014. DasarDasar Manajemen Keuangan. Salemba Empat. Jakarta

Budisantoso dan Nuritomo. 2013. Bank dan Lembaga Keuangan Lain. Jakarta. Salemba Empat.

Bukair, A. A. A. 2018. Factors Influencing Islamic Banks' Capital Structure in Developing Economies. Journal of Islamic Accounting and Business Research, 10(1), 2-20.

Chandrarin, Grahita. 2017. Metode Riset Akuntansi Pendekatan Kuantitatif. Salemba Empat. Jakarta

Cortez, Michael Angelo and Susanto, Stevie. 2012. The Determinants Of Corporate Capital Structure : Evidence From Japanese Manufacturing Companies. Journal of International Business Research, 11(3), 121-133.

DeAngelo, Harry and Masulis, Ronald W. 1980. Optimal Capital Structure Under Corporate and Personal Taxation. Journal of Financial Economics, 8(1), 3-27.

Deitiana,Tita \& Anggraini, Evanti. 2014. Faktor -Faktor yang Mempengaruhi Leverage pada PT Astra International Tbk dan Anak Perusahaannya. Jurnal Siasat Bisnis, 18(1), 11-20.

Dendawijaya, Lukman. 2009. Manajemen Perbankan. Ghalia Indonesia. Jakarta

Edward, J. H. 2017. Faktor - Faktor yang Mempengaruhi Leverage pada Perusahaan Sektor Industri Agrikultur yang Terdaftar di BEI Periode 2007-2015. Jurnal Ilmiah Mahasiswa Universitas Surabaya, 6(2).

Firmanullah, Nurul \& Darsono. 2017. Faktor-Faktor yang Mempengaruhi Struktur Modal di Perusahaan 
Indonesia (pada Perusahaan Manufaktur yang Terdaftar di BEI Tahun 2011-2014). Diponegoro Journal of Accounting, 6 (3), 1-9.

Ghazali, I. 2013. Analisis Multivariate Dengan Program SPSS. Badan Penerbit Universitas Diponegoro. Semarang.

Hasibuan, Malayu. 2005. Dasar-dasar Perbankan. Bumi Aksara. Jakarta

Horne, James C. Van \& Warchowicz, John. 2012. Prinsip-prinsip Manajemen Keuangan. Terjemahan oleh Quratul'ain Mubarakah. Salemba Empat. Jakarta

Joni dan Lina. (2010). Faktor-faktor yang Mempengaruhi Struktur Modal. STIE Trisakti. Jurnal Bisnis dan Akuntansi, 12(2), 81-96.

Machmud, Amir \& Rukmana, 2010, Bank Syariah, Teori, kebijakan, dan Studi. Empiris di Indonesia. Erlangga. Jakarta.

Maulina, Gilda., Nuzula, Nila Firdausi \& Nurlaily, Ferina. 2018. Pengaruh Faktor-Faktor Penentu Struktur Modal terhadap Struktur Modal (Studi pada Perusahaan Manufaktur yang Terdaftar di Bursa Efek Indonesia periode 2014-2016). Jurnal Administrasi Bisnis (JAB), 58 (1), 156-165.

Modigliani, F \& Miller, M.H. 1958. The Cost of Capital, Corporation Finance and The Theory of Investment. The American Economic Review. 13(3), 261-297.

Mondher, K. 2012. Capital structure Determinants:New Evidence From French Panel Data. International Journal of Business and Management, 7(1), 214-229.

Rifai, Moh., Arifati, Rina, \& Magdalena M, Maria2015. Pengaruh Ukuran Perusahaaan, Struktur Modal dan
Pertumbuhan Perusahaan terhadap Profitabilitas Studi Pada Perusahaan Manufaktur di BEI Tahun 20102012. Jurnal Universitas Pandanaran. 1(1), 1-8.

Usman, D. 2014. Panduan Lengkap Structural Equation Modeling. Lentera Ilmu. Semarang.

Yaya, Rizal., Martawireja, Aji Erlangga \& Abdurahim, Ahim. 2009. Akuntansi Perbankan Syariah. Teori dan Praktik Kontemporer. Salemba Empat. Jakarta

Yuliana, Lyna \& Yuyetta, Etna Nur Afri. 2017. Analisis Faktor-Faktor yang Mempengaruhi Leverage Perusahaan (Studi Empiris Pada Perusahaan Manufaktur yang Terdaftar di Bursa Efek Indonesia Tahun 2013-2015). Diponegoro Journal of Accounting, 6 (3), 1-13.

Yusintha, Putria \& Suyandari, Erni. 2010. Analisis Faktor-Faktor yang Mempengaruhi Struktur Modal (Studi Empiris pada Perusahaan Manufaktur di Bursa Efek Indonesia). Jurnal Akuntansi dan Investasi, 11 (2), 179-188. 